https://helda.helsinki.fi

Co-constructing meaning and context in international teacher education

\author{
Hahl, Kaisa
}

2016-03

Hahl , K 2016 , ' Co-constructing meaning and context in international teacher education ', Journal of English as a Lingua Franca, vol. 5 , no. 1 , pp. 83-105 . https://doi.org/10.1515/jelf-2016-0004

http://hdl.handle.net/10138/231182

https://doi.org/10.1515/jelf-2016-0004

acceptedVersion

Downloaded from Helda, University of Helsinki institutional repository.

This is an electronic reprint of the original article.

This reprint may differ from the original in pagination and typographic detail.

Please cite the original version. 


\title{
Kaisa Hahl* \\ Co-constructing meaning and context in international teacher education
}

\author{
Merkityksen ja kontekstin yhdessä rakentamista kansainvälisessä opettajankoulutuksessa
}

\begin{abstract}
In teacher education, students not only construct content knowledge but examine theory through their own experiences to be able to apply it to practice in equitable education. Teacher education prepares students to a certain educational system and usually it is the one in which the students are themselves educated. International higher education programmes in countries where English is not an official language use English as a lingua franca (ELF) for teaching and learning. However, participants come to a communicative situation with their own history, past experiences, knowledge, and their own frames of reference. This article looks at an excerpt from a particular university teaching session in English-medium instruction (EMI) teacher education in Finland where a group of international students from diverse educational, linguistic, and cultural backgrounds negotiate for meaning and common understanding. A discussion about an ethical dilemma related to student assessment is analyzed qualitatively turn-by-turn to show how communicative resources help overcome mis- and nonunderstanding that stems from, besides linguistic difficulties, understanding contexts in different ways. The achievement of mutual intelligibility and individual learning required the participation of many to allow for the linguistic challenges of understanding less familiar varieties and uses of English, and interpret the cultural and contextual levels behind the utterances.
\end{abstract}

Keywords: co-construction of communication, English as a lingua franca, EMI teacher education, intelligibility, negotiation of meaning

Tiivistelmä: Opettajankoulutuksessa opiskelijat eivät ainoastaan rakenna sisältötietoa vaan tutkivat teoriaa omien kokemustensa kautta, jotta he voivat soveltaa sitä käytännössä oikeudenmukaisessa opetuksessa. Opettajankoulutus valmistaa opiskelijoita tiettyyn koulutusjärjestelmään ja yleensä se on sama, jossa opiskelijat ovat itse käyneet koulunsa. Kansainväliset ylemmän asteen koulutusohjelmat maissa, joissa englanti ei ole virallinen kieli, käyttävät lingua franca -englantia (ELF) opettamiseen ja oppimiseen. Osallistujat kuitenkin tuovat keskusteluun mukanaan oman historiansa, menneet kokemuksensa, tietonsa ja omat viitekehyksensä. Tässä artikkelissa tarkastellaan otetta opetustilanteesta englanninkielisessä aineenopettajankoulutuksessa Suomessa, jossa ryhmä kansainvälisiä opiskelijoita erilaisine koulutus-, kieli- ja kulttuuritaustoineen tekee merkitysneuvotteluita yhteisymmärryksen saavuttamiseksi. Keskustelu opiskelija-arviointiin liittyvästä eettisestä dilemmasta analysoidaan laadullisesti vuorosana vuorosanalta, jotta voidaan näyttää, kuinka kommunikatiiviset keinot auttavat selvittämään väärinymmärrystä ja ymmärtämättömyyttä, jotka johtuvat kielellisten vaikeuksien lisäksi kontekstien ymmärtämisestä eri lailla. Yhteisymmärryksen ja yksilöllisen oppimisen saavuttaminen vaati usean osallistujan yhteistyötä, jotta he selvisivät englannin kielen harvinaisempien variaatioiden ja käyttöjen aiheuttamilta haasteilta ja pystyivät tulkitsemaan ilmaisujen kulttuuriset ja kontekstuaaliset kerrokset.

Avainsanat: yhdessä rakennettu viestintä, lingua franca -englanti, englanninkielinen opettajankoulutus, ymmärrettävyys, merkitysneuvottelu

\footnotetext{
${ }^{*}$ Kaisa Hahl: University of Helsinki, Helsinki, Finland

E-mail: kaisa.hahl@helsinki.fi
} 


\section{Introduction}

Teacher education is generally speaking very national in orientation as each country educates its own teachers as suited to the particular context. Likewise student teachers are usually educated to be teachers in the same school system in which they grew up in. Additionally, teacher education is usually conducted in the official language(s) of the country and rarely in a lingua franca. In an international Englishmedium instruction (EMI) teacher education programme, the context of the present study, the situation is different as students may have spent their own school years in one school system and are now prepared to be qualified teachers in a different, unfamiliar one. Since late last century increasing numbers of EMI programmes have been set up in countries and universities where English is not an official language (Maiworm and Wächter 2014). Students in such programmes may come together with very different educational backgrounds along with their own history, past experiences, and knowledge. What often connects the students is a "shared non-nativeness" (i.e. English is used as a lingua franca, ELF; Hülmbauer 2009: 328), and a joint interest in a particular field.

There is a growing body of literature about ELF in higher education from various perspectives: for example, academic ELF generally (Mauranen 2012), lecture comprehension (Hellekjær 2010), cooperative ELF strategies (Björkman 2010; Hynninen 2011), and ELF in 'international' universities Jenkins 2013; Smit 2010). This work shows how English is strategically adapted as a lingua franca when it is put to use as a medium of instruction; how EMI effectively means ELFMI in contexts where students from different linguacultural backgrounds are involved. This paper is intended as a contribution to this existing research by considering the use of ELF in international teacher education where the language needs to provide a common means of communication across different linguacultural backgrounds. With increasing migration and immigration in various parts of the world, it can be assumed that there will be a greater need and demand for ELFMI teacher education. Huang and Singh (2014) conducted a study to develop a framework for testing EMI teaching to help improve EMI teacher education in Taiwan. A study by Hahl et al. (2014) investigated perceptions from both teacher educators and student teachers of their accommodation to EMI teacher education in Finland. They concluded that while adjusting to different levels of English competence by teachers and students is not without challenges, by incorporating more learner-centred, student-led activities and integrating ELF perspectives, teacher education pedagogy can be positively affected.

This qualitative study contributes to research in ELFMI teacher education and takes a close look at a particular university teaching session in teacher education in Finland where a diverse group of international students negotiate meaning and common understanding in the course of developing their pedagogic expertise in teaching their particular subjects. A discussion about an ethical dilemma related to student assessment is analyzed to show how the strategic use of communicative resources helps overcome intercultural mis- and non-understanding and serves to bridge diverse knowledge and experience on linguistic, cultural, and contextual levels. It seeks to show how the co-construction of effective communication requires the input and cooperation of many participants in order to allow for the challenges posed by variable uses of English and for an awareness of the sociocultural context behind the utterances. The aim of this article is to argue that both student teachers and teacher educators in EMI teacher education programmes, whether local or international, need to step out of their own frames of reference in order to cooperatively negotiate meaning between different contexts and stretch their perspectives to successfully find common ground for mutual understanding which would further individual learning.

\section{International ELFMI teacher education}

Teacher educators have a dual role as they both teach student teachers and teach them how to teach (Loughran 2006). Teachers are usually educated with reference to a particular school system with its 
predetermined educational policies and aims within which teachers are expected to practice their professional roles (see the Finnish context in Toom and Husu 2012). Thus international teacher education programmes likely have some students who are not familiar with the school system for which they are being qualified. However, previous education and knowledge must be taken into account in teaching and learning new content as new information needs to be constructed by building on the prior knowledge so that students learn and develop their conceptions (Biggs and Tang 2011). Previous knowledge is not only learned knowledge in schools and institutions but it encompasses experiences all the way from childhood, through adolescence and into adulthood, and moulds a person's perspectives and frames of reference. Johnson (1997) argues that theoretical knowledge gained during teacher education must be renegotiated and examined in the context of one's own learning and experiences in order for it to have relevance and effect in practice:

If teachers do not examine the theoretical knowledge they master in their education programs within the familiar context of their own learning and teaching experiences, if that knowledge is not situated within the social context where it is to be used, if the interconnectedness of that knowledge is not made obvious, and if teachers have few opportunities to use that knowledge in situated and interpretative ways, then theory will continue to have little relevance for practice. (Johnson 1997: 781)

Although Johnson's argument relates to language teacher education, it is possible to be expanded to relate to teacher education whatever the subject. When expanded to international teacher education, student teachers need to be provided with ample opportunities to make connections between their own experiences and learning from their own contexts to those of the others and find points of convergence or divergence in them. Students also need to be encouraged to discuss and deliberate on their experiences and knowledge in connection with theory. Such examination will help to improve their critical understanding of the implications and consequences of their own decisions and actions as teachers (Hawkins 2004). Teachers must be prepared to be lifelong learners to be able to teach their students "within complex socially, culturally, and historically situated contexts" (Johnson 2006: 239).

Power relations are always in play in interactions. It may be the interlocutors' social status, position or language skills that create power differences (Dervin 2011; Piller 2011). In institutionalized settings in a classroom, teachers tend to hold more power than students (Cazden 2001). Traditional university lectures are often monologic in form although input from students may be encouraged. Where English is used to mediate linguacultural differences, as in the use of ELF, an imbalance of power and inequality may be even more pronounced (Shi-xu 2001). Although ELF speakers are usually willing and able to use various strategies to overcome mis- and non-understanding (as discussed next in Section 3), an ELFMI setting tends to incur certain challenges in the teaching and learning environment. One factor that may create challenges are speakers' varying degrees of English proficiency at different linguistic levels. Power differences are also created from within a person's attitudinal value placements (Jenkins 2007). Piller (2011: 132) claims that "[w] hite native speakers of English are privileged to live with the illusion that their accents are neutral, standard and natural." Yet even ELF speakers may place hierarchical value on different aspects of ELF (Jenkins 2007). This is in spite of increasing travel, migration, relocations, and instant transnational online communication that have resulted in a continuous mixing of different varieties and uses of English from the Inner, Outer and Expanding Circles (see Kachru 1986; Seidlhofer 2004). University lecturers in ELF contexts or non-native English teachers may sometimes feel their professionalism threatened due to their less-than-fluent language skills or nonnative accents (Golombek and Jordan 2005; Hahl et al. 2014; Pilkinton-Pihko 2010). Teaching in English as a lingua franca may also have effects among the students. Different studies have proposed that students' lecture comprehension may be lower in ELF settings than in the first language (Hellekjær 2010); students are less interactive in ELF lectures, i.e. they ask and answer questions less willingly 
(Airey and Linder 2006); and the content and academic knowledge of students in international programmes is more heterogeneous (Wächter and Maiworm 2008).

English as a lingua franca is characterized by a detachment from specific cultural assumptions and communicative norms traditionally attached to native languages (Baker 2009). Nevertheless, as people come to a communicative situation from different backgrounds (linguistic, cultural, social, professional, emotional, etc.), they bring along their own (educational) experiences and knowledge of different contexts and their own frames of reference. Reaching mutual intelligibility does not merely entail understanding the words in an utterance; their meaning and related context must also be understood. According to Smith and Nelson (1985), intelligibility is a three-stage process: words, utterances and therefore discourses need to be first intelligible (i.e. individual words and utterances are recognizable) before being comprehensible (their meaning is recognizable), and finally interpretable (the speaker's intention is recognizable). Usually this means that speakers have a sufficient level of communicative competence and a shared sociocultural background. Where this cannot be assumed, as in ELF settings, interlocutors may need to exert more effort to understand each other and they "need to bridge their divergent backgrounds and proficiency levels" in order to reach intelligibility (Smit 2009: 210). While academic discourse communities around the globe may well share many conventions that are familiar to different participants, there must be adjustments and negotiation for suitable ways of action in international ELFMI (teacher education) programmes to allow sufficient space for the negotiation of meaning and deliberation (see e.g. Mauranen 2010). Learning happens in interaction and thus socialization and sharing should be important aspects of academic practices (Biggs and Tang 2011). Such interactive socializing necessarily poses a challenge when interactants cannot assume common linguacultural norms so that sharing has to be negotiated through the use of ELF.

\section{Cooperativeness in ELF}

While English as a lingua franca communication does not require adherence to a standard variety of English, a relatively high level of language command is usually called for in academia (Hahl et al. 2014; Hellekjær 2010; Mauranen 2006). Several studies show, however, that language proficiency is not as important as the speaker's skill to effectively accommodate to the communicative situation by adapting and altering one's speech and communicative behaviour to better match that of the interlocutor (e.g. Björkman 2010; Mauranen 2010, Seidlhofer 2009).

Some factors that have been considered helpful in bridging the gap created by a lack of shared traditions, are non-nativeness, the ability to adapt hearing and speech according to the conversation taking place (Jenkins 2007), the speakers' orientation to content, and a common concern for the achievement of a shared meaning (Mauranen 2012; Seidlhofer 2011). Especially, but not only, when speakers share more than one language, they can use code-switching as a way to enhance understanding (Cogo 2009; Klimpfinger 2009). Cooperativeness and accommodation characterize ELF talk and allow for negotiating meaning and co-constructing communication. This is achieved by a repertoire of different strategies that help regulate and modify language use and allow for the assurances of comprehension (Cogo 2009; Kaur 2009). Speakers tend to signal misunderstanding, make a problem explicit and use confirmation checks to ensure that others understand (Mauranen 2006).

The accommodation or repair strategies can be either preventative or remedial (Kaur 2009). In the former the speaker is proactive and engages in certain practices to foresee a problem and thus avoids it. The speaker can, for example, repeat or paraphrase his/her own utterance (Björkman 2010; Kaur 2009; Lichtkoppler 2007). Instead of merely repeating a previous utterance, paraphrasing "involve[s] transformations in the syntactic structure and the lexical compositions of a prior utterance" (Kaur 2009: 110). In paraphrasing the speaker says the prior utterance in other words in order to make it more explicit 
or concrete so that the utterance becomes intelligible, comprehensible and interpretable to the interlocutor(s) (Smith and Nelson 1985).

Repair is a fundamental mechanism of conversation and relevant to all talk, not merely in ELF (Liddicoat 2009). Besides self-repair, remedial strategies can be other-repair or interactive repair when one or more interlocutors intervene to help the flow and understanding of the conversation. The term 'mediation' has been used in a particular sense to refer to the process when it is another person who paraphrases someone else's speech in order to further common understanding. Mediation thus involves the intervention of a third party in order to clarify apparent communicative misunderstanding by two or more co-speakers. In university contexts, mediation has been found as a strategy used by teachers (Hynninen 2011) and by students (Hahl et al. 2014) when taking the role of an intermediary to facilitate communication by interpreting and clarifying previous utterances to further understanding. Cooperativeness is a necessary feature of speakers in situations with a need to even out differences in the speakers' command of English and lack of shared social and cultural assumptions.

This article seeks to show empirically how these features of co-operative ELF use are realized in a particular case. It analyzes a discussion in international teacher education where the participants use linguistic resources to reach common understanding. The aim of this article is to argue that reaching mutual understanding requires negotiating meaning on linguistic, cultural, and contextual levels, which necessitates the participants to widen their own frames of reference and find anchoring points in their own experiences in order to transfer meaning between the contexts.

\section{Methodology}

This qualitative study is set in a course of international ELFMI teacher education at a university in Finland. The course was part of the first implementation of a whole unit of subject teacher education (in total 10 ECTS credits, equivalent to 270 hours of student work) one year prior to the formal start of the programme for subject teachers (of foreign languages, mathematics and science subjects, typically teaching 13-19-year-old students). This course started off the whole unit to give a general overview of subject teaching and was lecture-based (1 ECTS credit; 8 hours of lectures, individual study, and an exam). It thus differed from the other parts that also included interactive small group work and school visits. It was both video and voice recorded (the researcher was present to record but did not participate or intervene in the session in question). This study scrutinizes a 10-minute excerpt of a session that is part of a video and voice corpus that was recorded during the course in a month's time. The excerpt presents a discussion that deals with a question about an ethical dilemma that one of the students asked as related to teachers' assessment of students. The excerpt is chosen as data for this study because it is from the very end of the first day of teaching when the students were not familiar with each other's backgrounds or accents yet. Furthermore, this excerpt clearly shows how the lecturer and students need to step out of their own frames of reference to negotiate meaning and context.

The class consisted of a diverse body of students who were recruited through the university mailing lists and were Bachelor, Master, and PhD students. The Finnish speakers in the group had already been accepted to the Finnish-medium teacher education programme but the non-Finnish speakers took the rare opportunity to study pedagogy in English. The only requirement for English proficiency in order to enter the course was the person's own estimation that s/he could study in English. Once the programme started officially, the university's regular language proficiency levels were incorporated and students had to apply through an aptitude test. The twelve students, with majors in either a humanities or a science subject, originated from Cameroon, Malaysia, United Kingdom, United States, and Finland. The lecturer (L) of the session had Finnish as first language and she was a proficient speaker of English. The group thus had native English speakers from the Inner and Outer Circles and non-native speakers from the Expanding Circle (see Kachru 1986). Although both Kachru's simplified model of Englishes and the 
dichotomy of native/non-native speaker are problematic ideas (see Seidlhofer 2011), they serve in this article as generalizations of the different kinds of English speakers and different kinds of Englishes spoken worldwide. The origins and first languages of the participants in the discussion in scrutiny are detailed in Table 1.

Table 1: Origins and first languages of participants in the discussion:

\begin{tabular}{|c|c|c|}
\hline Participant & Country of origin & Stated first language(s) \\
\hline L & Finland & Finnish \\
\hline S1 & Cameroon & English \\
\hline S2 & Cameroon & English and French \\
\hline S3 & United Kingdom & English \\
\hline S4 & Finland & Finnish \\
\hline S5 & Malaysia & English \\
\hline S6 & Finland & Finnish \\
\hline
\end{tabular}

A broad transcription method ${ }^{1}$ was deemed suitable as the purpose of this study was not to concentrate on 'deviations' and unconventional forms but "to gain understanding of how communication occurs in relation to situated practices and through continual contextualisation" (Baird et al. 2014: 188). Because the accents of the two most active students in the excerpt were uncommon from a European perspective and rather difficult for the author to understand, another researcher familiar with the accents was engaged in the transcription process. The parts that he deciphered are in parentheses in the extracts, i.e. shown as unclear speech. The discussion is analyzed qualitatively in order to "understand [the] shared procedures which participants in an interaction use to produce and recognize meaningful action" (Liddicoat 2009: 7). In agreement with Deterding and Kirkpatrick (2006: 392), although through the analysis intelligibility can gradually be seen to be reached, it is not possible to be absolutely certain how intelligible the participants found the interlocutors' contributions in every turn. The analysis pinpoints the strategies helpful to ELF talk (see Section 3) that the speakers engaged in and brings forth the turning points that become evident as mutual understanding is gradually achieved and the different contexts negotiated.

\section{Negotiating meaning and context}

This section will go through the chosen discussion turn-by-turn to bring up the different turn-takings and strategies that the interlocutors engaged in when solving the question about an ethical dilemma related to student assessment asked by one of the students (S1). The moment required the participation of many so that the relevance of the question became clear for all and so that the participants found meaningful associations with the question.

Although the four-hour teaching session was mostly teacher-led, the lecturer had begun by inviting student participation and there was continuous dialogue throughout:

\footnotetext{
${ }^{1}$ The transcription is broad and pronunciation deviations are usually not transcribed. The conventions used: (.) a short pause of any length; [ overlapping speech starts; ( ) transcription not possible; (word) unclear speech; [action] action in class explained; /.../ cut-out speech.
} 
now we're gonna do really traditional lecturing (.) although i do hope that er you interrupt me and ask questions any time you like (.) erhm so that we are in a dialogue rather than than just me lecturing to you

The session had thus been enriched by students' questions and comments, also by student S1. The session had previously included a wide range of topics, such as "Teaching-studying-learning process," "Didactic triangle" and "Ethics: Morality in teaching." The lecture about ethics related to teachers' personal values versus professional ethics, and ethical challenges that arise when the morals of different actors in school (teachers, students, parents) are in a constant dialogue. This topic had not given rise to any questions or comments from the students at the time. The topics prior to the final discussion had concentrated on teachers' roles, personality, and development. The lecturer had already thanked the students for the day and ended the session, and thus some students had already stood up to collect their belongings in order to leave when student S1 spoke up and posed a question.

The right-hand side column in the extracts below show the speaker utterances, the left-hand side column explains the strategies used in the discourse or turning points in the conversation (numbers in bold). The columns in the middle show the order of the turn-takings (numbers in italics) and the speaker. The students are numbered in the order they speak up. The discussion starts off with Extract 1 where the interactants clarify the topic of the question:

Extract 1: Clarification of topic

\begin{tabular}{|c|c|c|}
\hline & $1 \quad \mathrm{~S} 1:$ & $\begin{array}{l}\text { just one question [some students are already up } \\
\text { collecting things and getting ready to leave but then sit } \\
\text { back down] }\end{array}$ \\
\hline & $\mathrm{L}:$ & yes \\
\hline 1) QUESTION & S1: & $\begin{array}{l}\text { what does the (.) ethics says about a teacher (penalizing } \\
\text { a student by deleting) the- }\end{array}$ \\
\hline $\begin{array}{l}\text { 2) CLARIFICATION } \\
\text { REQUEST }\end{array}$ & L: & $\begin{array}{l}\text { i'm sorry (.) the (.) didactic did you mean the didactical } \\
\text { triangle }\end{array}$ \\
\hline 3) REPETITION OF TOPIC & S1: & no i'm talking about ethics \\
\hline 4) CONFIRMATION & L: & ethics \\
\hline $\begin{array}{l}\text { 5) REPETITION OF } \\
\text { QUESTION + } \\
\text { ADDITIONAL } \\
\text { INFORMATION }\end{array}$ & S1: & $\begin{array}{l}\text { yes what does the ethics says (.) about a teacher } \\
\text { penalizing a student by deleting the student's point } \\
\text { (maybe the student has fifteen or twenty and) (.) because } \\
\text { the student is ( ) (with the teacher the teacher goes and } \\
\text { takes off ten points (.) and the) student (might end up just } \\
\text { failing) (.) what does ethics says about that kind of } \\
\text { situation }\end{array}$ \\
\hline $\begin{array}{l}\text { 6) SIGNALLING NON- } \\
\text { UNDERSTANDING }\end{array}$ & $8 \quad$ L: & $\begin{array}{l}\text { oh i'm not sure now i understood your question correctly } \\
\text { (.) uhh [lecturer moves closer to the students from } \\
\text { behind the desk] could you could you repeat one more } \\
\text { time }\end{array}$ \\
\hline 7) REPHRASE & S1: & $\begin{array}{l}\text { like a classroom teacher (.) decide to penalize a student } \\
\text { (.) maybe for arrogant action (.) by making the student } \\
\text { fail the exam (.) so what does teaching ethics says about } \\
\text { that (.) is it allowed }\end{array}$ \\
\hline $\begin{array}{l}\text { 8) PARAPHRASE + } \\
\text { CONFIRMATION } \\
\text { REQUEST } \\
\text { INTELLIGIBLE }\end{array}$ & 10 & $\begin{array}{l}\text { oh you would have to look at the specific er (.) codes of } \\
\text { the school but uh (.) if you are talking about failing a } \\
\text { student because of misbehaviour (.) is that what you are } \\
\text { asking }\end{array}$ \\
\hline 9) CONFIRMATION & 11 S1: & sure \\
\hline $\begin{array}{l}\text { 10) ANSWER } \\
\text { COMPREHENSIBLE }\end{array}$ & $12 \mathrm{~L}:$ & sure (.) no that would not be correct \\
\hline
\end{tabular}


(1) Student S1 first catches the lecturer's attention in the commotion at the end of the session and then asks a question. (2) The lecturer cannot hear him and thus asks for a clarification and suggests a topic. (3) S1 rejects the lecturer's suggestion and repeats the correct topic, (4) which the lecturer confirms. (5) S1 repeats his question and elaborates more on it. (6) The lecturer still cannot catch the student's meaning and signals non-understanding by direct words and by moving closer to $\mathrm{S} 1$ from behind her desk. (7) S1 then rephrases his question for the third time, and (8) now the lecturer paraphrases his question and yet asks for confirmation of whether she has understood correctly. The lecturer has now reached the first level of understanding; she finds the words in the utterance recognizable (intelligible) (Smith and Nelson 1985). (9) As S1 gives her the confirmation, (10) the lecturer reaches the second level of intelligibility; she recognizes the meaning of the question (comprehensible) and is able to give the student an answer.

Both S1 and the lecturer have so far used common and essential strategies in ELF discourse in order to overcome misunderstanding and non-understanding. The lecturer has clearly signaled her nonunderstanding and asked questions for clarification and paraphrased S1's question. The student has repeated and rephrased his question. Although the lecturer is finally able to give the student an answer, this does not satisfy him. The discussion continues with Extract 2:

\section{Extract 2: Rephrasing own speech}

\begin{tabular}{|c|c|c|}
\hline $\begin{array}{l}\text { 11) REPHRASE OF } \\
\text { QUESTION }\end{array}$ & 13 S1: & $\begin{array}{l}\text { or if student is making a different action and teacher (.) } \\
\text { because of (certain) reason (.) decide to penalize the } \\
\text { student just by making to fail the student just }\end{array}$ \\
\hline \multirow[t]{4}{*}{$\begin{array}{l}\text { 12) REPHRASE OF } \\
\text { ANSWER }\end{array}$} & 14 & $\begin{array}{l}\text { no (.) failing a student would have to be with the (.) uh } \\
\text { the success in that (.) content area so (.) not on just based } \\
\text { on misbehaviour or something like that }\end{array}$ \\
\hline & S1: & $\begin{array}{l}\text { so is it part of ethics because i didn't get it from the } \\
\text { lectures (.) uh teaching ethics }\end{array}$ \\
\hline & 16 & 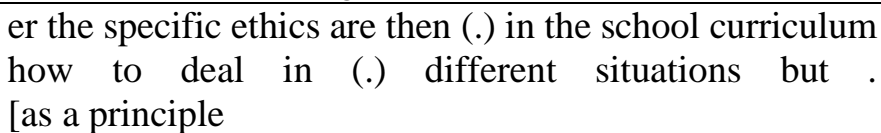 \\
\hline & S1: & $\begin{array}{l}\text { [so so which means that (.) which means (then that) } \\
\text { maybe an institution may actually give the right }(.) \text { for } \\
\text { teachers (.) to penalize students by just failing them . }\end{array}$ \\
\hline $\begin{array}{l}\text { 13) REQUEST FOR HELP } \\
\text { FROM OTHERS }\end{array}$ & 18 & $\begin{array}{l}\text { right so [lecturer looking at other students for help] do } \\
\text { you (.) do you understand where [another student starts } \\
\text { speaking] yes }\end{array}$ \\
\hline
\end{tabular}

(11) S1 rephrases his original question because he is clearly looking for confirmation or elaborationthe simple answer was not sufficient. From the video it is quite clear that the lecturer does not comprehend why S1 is asking such a question. (12) The lecturer rephrases her answer and explains that failing a student needs to be based on his/her performance related to learning the content of the class. Ethics in teaching were discussed earlier in the session but in a more general sense. In a way S1 is questioning the content of the lecture (turn 15).

S1 continues by asking a follow-up question and then (turn 17 above) suggests that perhaps some institutions could give their teachers a right to fail a student merely based on misbehaviour. (13) The lecturer does not seem to follow S1's line of thought and does not understand what he is aiming at. She is not able to answer S1's question and thus looks around the room and requests for others to get 
involved. In Extract 3, student S2 jumps in the discussion to explain in different words what S1 has attempted to say:

Extract 3: Mediation

14) MEDIATION $\quad 19$ S2: $\quad \mathrm{i}$ think the curriculum is (based) on equality (.) in every school (.) and if the student commits a crime (.) or is against the teacher (in any way the) teacher has no right to fail the student based on (his personal) judgment (.) you have the right to judge the student based on assessment (.) and if the student continues or is (.) misbehaving in (class then the only thing you have to do (.) is to) take (the matter) up to the authority (.) (they will know better whether to discipline the student failing a student is your) (.) if you fail a student (you are taking your own) personal judgment (to fail the student) (.) and you can be punished as a teacher

Mediation works as a strategy when another person joins in to help the interlocutors to understand each other (Hynninen 2011). Here, S2 understood the original context that S1 was trying to portray to the class. S2 also explains the idea that the lecturer had tried to convey to S1; thus he mediated both ways. In this extract it is noticeable that the vocabulary $\mathrm{S} 2$ is using is different from what is commonly used in the Nordic context of education. S2 uses terms such as "commits a crime" (misbehaves), "judge the student based on assessment" (assess student based on performance/behaviour), and "the authority" (principal). In Extract 4, other students also get involved in the discussion:

\section{Extract 4: Suggestions for other courses of action}

\begin{tabular}{|c|c|c|}
\hline & 20 S1: & that's exactly what i wanted to hear (.) whether \\
\hline & 21 L: & [yes thank you that's the way-i thank you \\
\hline & 22 S1: & $\begin{array}{l}\text { [if ethics of teacher (.) if ethics of teaching actually (.) } \\
\text { (inform the) teacher (that (.) if you use) this kind of } \\
\text { method to penalize the student (.) (you can be sanctioned } \\
\text { for) }\end{array}$ \\
\hline & 23 L: & $\mathrm{hmm}$ \\
\hline \multirow[t]{2}{*}{$\begin{array}{l}\text { 15) SUGGESTIONS FOR } \\
\text { OTHER COURSES OF } \\
\text { ACTION }\end{array}$} & 24 S3: & $\begin{array}{l}\text { i think (i think normally there's) some other kind of } \\
\text { method (that you could) indicate that a student has } \\
\text { behaved badly by (.) some other er assessment (behaviour } \\
\text { assessment behaving or some other thing) (.) you } \\
\text { wouldn't (.) you wouldn't penalize them on the test }\end{array}$ \\
\hline & 25 S1: & $\begin{array}{l}\text { in certain universities or in universities (.) some teachers } \\
\text { they (.) might not want (certain) questions (so when the } \\
\text { student question them they will say okay) (.) now you } \\
\text { will never pass my my my course until (.) (until you are } \\
\text { transferred) }\end{array}$ \\
\hline $\begin{array}{l}\text { 16) SUGGESTIONS FOR } \\
\text { OTHER COURSES OF } \\
\text { ACTION }\end{array}$ & 26 S4: & $\begin{array}{l}\text { you have to think about the goals (.) why you punish for } \\
\text { that }\end{array}$ \\
\hline
\end{tabular}

S1 seems content with the answer that failing a student based on misbehaviour is indeed not an ethical course of action (turn 20 above). Perhaps because of his accent, no one picks up when he wonders whether the code of ethics in teaching "actually inform the teacher that [...] you can be sanctioned for" 
wrongful methods against students (turn 22). The others may also think that if it is important, it "will become clearer as the interaction progresses" (Deterding and Kirkpatrick 2006: 392).

Other students then get involved and suggest alternate courses of action for a teacher in such a situation. (15 above) Student S3 brings up that if a student has misbehaved, the teacher should use other methods or ways for reacting to such behaviour, instead of penalizing for it on a test. (16) S4 reminds the others that the teacher needs to keep in mind the criteria for discipline and the reasons behind it. The discussion continues in Extract 5 with a follow-up example of an ethical problem from S1:

\section{Extract 5: Repetition and rephrasing}

\begin{tabular}{|c|c|c|}
\hline & 27 S1: & $\begin{array}{l}\text { so if a teacher takes that kind of decision }(.) \text { you as a } \\
\text { student }(.) \text { (you already you notice that) (.) no matter how } \\
\text { you (do (.) you can't pass an exam because the same } \\
\text { master) the same lecturer is there (.) (each time you are } \\
\text { restricted (.) he just grades you lower grade he doesn't } \\
\text { even mind to read you work) ( ) }\end{array}$ \\
\hline & 28 S2: & can i say something \\
\hline & 29 L: & yes please \\
\hline $\begin{array}{l}\text { 17)MEDIATION; } \\
\text { REPETITION + } \\
\text { REPHRASING }\end{array}$ & $30 \quad$ S2: & $\begin{array}{l}\text { i understand what he is saying (.) but er er the problem is } \\
\text { that (you know that) with most institution they always } \\
\text { favours the teacher } \\
\text { they always back (the teacher (.) when the teacher makes } \\
\text { his) decision (.) and he (.) like a colleague in the school } \\
\text { (.) or he's part of the school (.) part of the administration } \\
\text { whatever the teacher says is more (.) is widely believed } \\
\text { by the authority (.) rather than what the student says (.) } \\
\text { so the teacher could even fail the student (.) and or if he } \\
\text { do something more (.) anything against the student and } \\
\text { tells the authorities something else they would believe } \\
\text { (him without verifying) (.) that is (the the the point where } \\
\text { you see (.) let me say i can call it ethical failure) (.) where } \\
\text { it is not (proven) (.) in certain ways (.) but in certain } \\
\text { situation it is also the (problem) when (.) the teacher fails } \\
\text { you and you (.) you know you have performed very well } \\
\text { an assessment (.) you could report to the authority (to to } \\
\text { to crosscheck your script (.) and) they can crosscheck it } \\
\text { and put everything in order } \\
\text { (but when) (.) if the authority believes more on the } \\
\text { teacher then the student has to be (.) (will be on the } \\
\text { negative side) }\end{array}$ \\
\hline
\end{tabular}

S1 explains a situation where a lecturer has decided not to give a passing grade to a student even if s/he retakes the exam (turn 27 above). (17) S2 realizes that the lecturer did not understand S1's point, and thus he engages in mediation again. In S2's experience (and alike with that of S1), the teacher is more powerful and his word would always be believed over that of the student. S2 uses a series of repetitions and rephrasing (underlined in turn 30, total of five times) to thoroughly explain in different ways that "most institution they always favours the teacher." The comprehension of whole utterances is not always necessary as long as a basic understanding is relayed (Deterding and Kirkpatrick 2006: 392). However, $\mathrm{S} 2$ takes proactive measures to make sure that he gets his point across.

In the following, Extract 6, mutual understanding about the purpose of the original question is finally reached: 
Extract 6: Reaching mutual understanding

\begin{tabular}{rrrl}
\hline 31 & L: & but uh (.) would any teacher behave so unethically \\
\hline 32 & S2: & yeah some do \\
\hline 33 & S1: & yeah some do i've experienced it \\
\hline 34 & S2: & $\begin{array}{l}\text { yeah i'm talking we're he's talking like that from } \\
\text { experience i i i understand what he's saying from my } \\
\text { experience }\end{array}$ \\
\hline 35 & S5: & $\begin{array}{l}\text { i understand it too from experience [laughing] so it's not } \\
\text { a european phenomenon maybe }\end{array}$ \\
\hline 36 & S1: & $\begin{array}{l}\text { (so you go to the authority the authority) tells you go and } \\
\text { settle the matter (.) } \\
\text { [back with the teacher }\end{array}$ \\
\hline 37 & S2: & $\begin{array}{l}\text { [back with the teacher and so you don't have anything to } \\
\text { do }\end{array}$ \\
\hline 38 & S1: & teacher says i don't want to see you \\
\hline 39 & S2: & $\begin{array}{l}\text { i don't want to see you you can't come to my office and } \\
\text { that kind of a thing how do you (.) how do you survive in } \\
\text { that situation }\end{array}$ \\
\hline 40 & L: & okay (.) now i understand what you are talking about \\
\hline 41 & S2: & so that is the problem \\
\hline 42 & L: & yes yes \\
\hline & &
\end{tabular}

In turn 31 the lecturer understands the point and the injustice that S1 and S2 were raising. However, the lecturer wonders whether such action would be taken by any teacher. In turn 35 another student besides S1 and S2 also chimes in and says that she has experienced such an injustice as well. In turns 36-39 S1 and S2 explain how the authority (presumably principal) may not believe the student and s/he is powerless. In turn 40, the lecturer is finally able to interpret the issue of ethicality behind S1's original question and recognizes the speaker's intention (interpretable). As can be deduced for example from turn 31, such a situation seems far from the reality and the cultural context that the lecturer has experienced. Combined with the language that has partly been difficult for her to understand, it has taken numerous turns and explanations for the core of the matter to be fully comprehended. The discussion continues and concludes in Extract 7:

Extract 7: Transferring meaning to local context and teacher education

\begin{tabular}{|c|c|c|}
\hline & $43 \quad$ S1: & $\begin{array}{l}\text { so it's really important for me (.) to understand what what } \\
\text { what ethics teaching ethics says about that kind of } \\
\text { situation (.) (there is that) (.) like he (rightly) said it is } \\
\text { specific it is right that some teachers they (take advantage } \\
\text { of that and take situations) into their own hands }\end{array}$ \\
\hline & $44 \quad \mathrm{~L}:$ & $\begin{array}{l}\text { so what are your rights as a teacher (.) what are your } \\
\text { responsibilities as a teacher (.) okay (.) i see }\end{array}$ \\
\hline & $45 \quad \mathrm{~S} 1:$ & $\begin{array}{l}\text { and in education when it comes to giving sanctions to } \\
\text { students }(\mathrm{C} \text {. }\end{array}$ \\
\hline $\begin{array}{l}\text { 18) TRANSFERRING } \\
\text { MEANING TO LOCAL } \\
\text { CONTEXT }\end{array}$ & $46 \quad$ S6: & $\begin{array}{l}\text { actually i think in finland (.) the problem is not in that } \\
\text { direction (.) it's rather in a positive direction (.) if you } \\
\text { behave well you get better grades (.) like that kind of } \\
\text { hidden curriculums }\end{array}$ \\
\hline $\begin{array}{l}\text { 19) RELATING THE ISSUE } \\
\text { TO TEACHER } \\
\text { EDUCATION }\end{array}$ & 47 S3: & $\begin{array}{l}\text { i think that's like a question (.) how does the teacher } \\
\text { maintain er equality in class when you're thinking about } \\
\text { assessing the children (.) obviously there are some } \\
\text { children who are like really punctual and behaving well }\end{array}$ \\
\hline
\end{tabular}


and doing their work and some others who maybe couldn't ( ) in the world (.) so they can't keep up that kind of (balance)

$48 \quad$ S2 i think even though it could be positive in finland but (.) maybe aspects of it should be taken into consideration

49 S6: yeah

50 L: $\quad$ yes $/ \ldots /$

In turn 44 the lecturer sums up what is it that S1 really wants to find out: "so what are your rights as a teacher what are your responsibilities as a teacher". (18) Student S6 joins the discussion and transfers meaning to local context by bringing up that in Finland teachers might more often go wrong in the other direction and grade well-behaving students better than what their performance actually is. (19) S7 brings the issue further and relates the discussion topic to teacher education: "how does the teacher maintain equality in class."

\section{Discussion}

The analysis of these interactions would seem to substantiate other findings reported in the literature that the achievement of understanding in an English as a lingua franca setting involves the bridging of knowledge and experience on different levels: linguistic, cultural, and contextual.

Students S1 and S2 were different in their uses of linguistic strategies. S1's pronunciation seemed harder for the interlocutors to understand but he did not seem to take it into account in his way of speaking. On the contrary, although the other students and the lecturer seemed to understand S2 better, he took a more pre-emptive role in ensuring that the others would understand him by rephrasing his point even several times in one turn. S1's strategies were remedial as he repeated and rephrased after mis- or nonunderstanding happened (Björkman 2010; Kaur 2009). S2's role as a mediator was important in this communicative situation as he shared the sociocultural and educational background with S1. Mediation involved not only a linguistic level but cultural and contextual levels as well. Without S2's presence the co-construction of common understanding would likely have taken longer. In ELF contexts, however, it is usual that participants do not share similar sociocultural or educational backgrounds and thus it cannot always be relied on to have such a mediator present who shares one's own experiences. Therefore it is important to compare and contrast experiences and contexts to find commonalities, and this finding of commonalities can only in this case be achieved by exploiting the resources of ELF as a common means of communication.

Negotiating meaning - or even understanding the meaningfulness of a question or a comment - can sometimes be problematic among students from diverse educational backgrounds with varied kinds of Englishes. If there is a student in an EMI programme whose language is more difficult for the interlocutors to understand, it is yet vitally important that the lecturer and fellow students patiently give time and space to work at reaching understanding, as happened in this example. The analysis of the discussion also emphasizes the significance of signaling non-understanding so that effort is exerted to draw from the communicative resources available in order to reach mutual understanding (Mauranen 2006, 2010). The lecturer in this study serves as an example that teachers in (ELF higher) education need to be confident and willing to invite students to participate-without worrying about losing credibility or authority or without worrying about any supposed 'deficiency' in English - if and when they cannot understand the meaning or context of a student's question or comment (Hahl et al. 2014). Nevertheless, without the interest, involvement, and perseverance of the other students, crucially mediated through their use of ELF, the matter would likely not have been solved. 
Finding common ground required examples and experiences from different contexts (Loughran 2006). Although most of the students could not directly relate to the injustice that students S1 and S2 brought up and had not experienced such incidents themselves, they did not stop to merely marvel at an oddity (or leave the class as the lecture was over) but endeavored to transfer meaning locally. While the setting was a teacher-led lecture with its assumed institutional power relations and interactional conventions, it was yet the participants who jointly negotiated the participatory roles and it was ELF that provided the necessary enabling conditions for them to do this. Perhaps due to a combination of the small class size, the novelty of the event, and the heterogeneity of the group, the students indeed repeatedly heeded the lecturer's invitation to "interrupt and ask questions" (cf. Airey and Linder 2006). The students went beyond just asking questions, however, and it was them, rather than the lecturer, who took a proactive role in transferring meaning to a context familiar to them and considering what a related case could be in the local context. The students also considered what the questions meant from the point of view of teacher education and what alternate actions a teacher should or could take in a situation of a student's misbehaviour. Professional learning is more effective when students reflect on their own experiences and have space to share it together (Johnson 1997, 2006). The central point is, however, that in this case the shared space could only be created by the use of ELF.

\section{Conclusion}

As this study proposes, when students are given space to construct their own understanding without the lecturer always giving ready-made answers, and without being inhibited by conventional norms of correctness in the use of English, it allows students to develop their conceptions from a base they are familiar with and helps to even out the traditional teacher/student dichotomy (Biggs and Tang 2011; Loughran 2006). It needs to be kept in mind that although utmost care has been taken, the transcript is not an objective account of the actual discussion. The researcher has made her own interpretations of the interaction and strategies undertaken in the discussion, with the video as an aid, to decipher the meaning of the different turn-takings and action in class. Nevertheless, this study highlights the necessity that in EMI programmes all students and teachers from any origin need to be prepared to go beyond their own frames of reference and widen their perspectives to negotiate the meaning of different contexts to successfully achieve mutual intelligibility and further individual learning. The analysis also accentuates a demand that all participants in international programmes are introduced to the principles of ELF communication (Seidlhofer 2011; see also Dewey 2012). English speakers from Kachru's (1986) all three Circles will benefit from learning to accommodate their talk to that of the interlocutor in order to become more efficient communicators.

Teachers need to listen closely to students' questions and concerns and ensure their understanding as well as invite them to share meaningful examples of contextual differences. Simultaneously, students need to take responsibility for their own learning and take initiative in further inquiries in case they are not certain that they have understood the issue and context correctly. As this study shows, however, it may be impossible for the lecturer - in particular in a new international teacher education programmeto know when to give more time for discussion or what topics require more thorough examination from one or more of the students. As content and contexts may require more negotiation in ELF settings, sufficient time should be incorporated for student input and inquiries. Such negotiation of course places a premium on the effective communicative use of ELF.

Teaching is ingrained with normative elements that are based on established values, just as the conventional idea of English is normatively ingrained. In (international) teacher education programmes it is important that concepts, guidelines, and norms are clarified and negotiated in such ways that involve student participation and which will enable student teachers to practice equitable education with their future students. In other words, it needs not to teach specific techniques but to develop a strategic 
capability and in this respect the aims of teacher education correspond closely with the kind of communicative capability that characterises ELF (Widdowson 2012). As this study shows, cooperative ELF communication strategies are integral in co-constructing meaning in international contexts. Teachers need to make daily decisions, of less or greater impact, based on their ethical values and understanding. Existing assumptions and values - of teachers and lecturers, too - need to be challenged and reflected on (Dervin and Hahl 2015), just as do existing assumptions and values associated with English. It is essential that students have ample opportunities to interpret and relate their prior experiences and interconnect them with the theoretical knowledge that they are expected to master within teacher education so that they are able to apply the knowledge in relevant and appropriate ways in practice (Johnson 2006). And when in the context of EMI their experiences are linguaculturally different, the students can only do this by means of ELF. Graduates from international ELFMI teacher education can thus gain valuable experience from having to negotiate meanings and contexts during training that they can carry along to teaching students in increasingly multicultural schools, in their first, second or additional languages.

Acknowledgments: This article is dedicated to my friend and colleague Ray Carey, who was an inspiration behind this article and always willing to lend his support and advice on matters related to ELF.

A sincere thank you to Aminkeng A. Alemanji for his help in transcribing the extracts. Thank you to Ray Carey, Kalle Juuti, Erika Löfström and Fred Dervin for their valuable comments and helpful suggestions on a draft of this article. I would also like to thank Barbara Seidlhofer, editor of JELF, and the two anonymous reviewers for their constructive and detailed comments that helped finalize this article.

\section{References}

Airey, John and Cedric Linder. 2006. Language and the experience of learning university physics in Sweden. European Journal of Physics 27(3). 553-560.

Baird, Robert, Will Baker \& Mariko Kitazawa. 2014. The complexity of ELF. Journal of English as a Lingua Franca 3(1). 171-196.

Baker, Will. 2009. The cultures of English as a lingua franca. Tesol Quarterly 43(4). 567-592.

Biggs, John B. \& Catherine Tang. 2011. Teaching for quality learning at university, 4th edn. Maidenhead, UK: Open University Press.

Björkman, Beyza. 2010. So you think you can ELF: English as a lingua franca as the medium of instruction. Journal of Language and Communication Studies 45. 77-96.

Cazden, Courtney. 2001. Classroom Discourse: The Language of Teaching and Learning (2nd edition). Portsmouth, NH: Heinemann.

Cogo, Alessia. 2009. Accommodating difference in ELF conversations: A study of pragmatic strategies. In Anna Mauranen \& Elina Ranta (eds.), English as a lingua franca: Studies and findings, 254273. Newcastle upon Tyne, UK: Cambridge Scholars Publishing.

Dervin, Fred. 2011. Cultural identity, representation and othering. In Jane Jackson (ed.), Routledge handbook of intercultural communication. London, UK: Routledge.

Dervin, Fred \& Kaisa Hahl. 2015. Developing a portfolio of intercultural competences in teacher education: The case of a Finnish international programme. Scandinavian Journal of Educational Research 59(1). 95-109.

Deterding, David \& Andy Kirkpatrick. 2006. Emerging South-East Asian Englishes and intelligibility. World Englishes 25(3/4). 391-409.

Dewey, Martin. 2012. Towards a post-normative approach: learning the pedagogy of ELF. Journal of English as a Lingua Franca 1(1). 141-170. 
Golombek, Paula \& Stefanie R. Jordan. 2005. Becoming "Black Lambs" Not "Parrots": A Poststructuralist Orientation to Intelligibility and Identity. In TESOL Quarterly 39(3). 513-533.

Hahl, Kaisa, Heini-Marja Järvinen \& Kalle Juuti. 2014. Accommodating to English-medium instruction in teacher education in Finland. International Journal of Applied Linguistics.

Hawkins, Margaret R. 2004. Social Apprenticeships Through Mediated Learning in Language Teacher Education. In Margaret R. Hawkins (ed.), Language Learning and Teacher Education: A Sociocultural Approach, 89-109. Clevedon, UK: Multilingual Matters.

Hellekjær, Glenn Ole. 2010. Language matters: Assessing lecture comprehension in Norwegian English-medium higher education. In Christiane Dalton-Puffer, Tarja Nikula \& Ute Smit (eds.), Language use and language learning in CLIL, 233-258. Amsterdam, The Netherlands: John Benjamins.

Huang, Da-Fu \& Michael Singh. 2014. Critical perspectives on testing teaching: reframing teacher education for English medium instruction. Asia Pacific Journal of Teacher Education 42(4). 363-378.

Hynninen, Nina. 2011. The practice of 'mediation' in English as a lingua franca interaction. Journal of Pragmatics 43. 965-977.

Hülmbauer, Corelia. 2009. "We don't take the right way. We just take the way that we think you will understand."-The Shifting Relationship between Correctness and Effectiveness in ELF. In Anna Mauranen \& Elina Ranta (eds.), English as a lingua franca: Studies and findings, 323347. Newcastle upon Tyne, UK: Cambridge Scholars Publishing.

Jenkins, Jennifer. 2007. English as a lingua franca: Attitude and identity. Oxford, UK: Oxford University Press.

Jenkins, Jennifer. 2013. English as a Lingua Franca in the international university: The politics of academic English language policy. Abingdon, UK: Routledge.

Johnson, Karen. E. 1997. The author responds... TESOL Quarterly 31(4), 779-782.

Johnson, Karen. E. 2006. The Sociocultural Turn and Its Challenges for Second Language Teacher Education. TESOL Quarterly 40(1). 235-257.

Kachru, Braj B. 1986. The alchemy of English: the spread, functions and models of non-native Englishes. Oxford: Pergamon Press.

Kaur, Jagdish. 2009. Pre-empting problems of understanding in English as a lingua franca. In Anna Mauranen \& Elina Ranta (eds.), English as a lingua franca: Studies and findings, 107-125. Newcastle upon Tyne, UK: Cambridge Scholars Publishing.

Klimpfinger, Theresa. 2009. "She's mixing the two languages together"-forms and functions of codeswitching in English as a lingua franca'. In Anna Mauranen \& Elina Ranta (eds.), English as a lingua franca: Studies and findings, 348-371. Newcastle upon Tyne, UK: Cambridge Scholars Publishing.

Lichtkoppler, Julia. 2007. "Male. Male."-“Male?"-_The sex is male." The role of repetition in English as a lingua franca conversations'. Vienna English Working Papers 16(1). 39-65.

Liddicoat, Anthony J. 2009. An introduction to conversation analysis. London, UK: Continuum.

Loughran, John. 2006. Developing a pedagogy of teacher education: Understanding teaching and learning about teaching. New York, NY: Routledge.

Maiworm, Friedhelm \& Bernd Wächter. 2014. Part I - The Big Picture. In Bernd Wächter \& Friedhelm Maiworm (eds.), English-taught programmes in European higher education: The state of play in 2014, 25-62. Bonn: Lemmens Medien.

Mauranen, Anna. 2006. Signaling and preventing misunderstanding in English as a lingua franca communication. International Journal of the Sociology of Language 177. 123-150.

Mauranen, Anna. 2010. Features of English as a lingua franca in academia. Helsinki English Studies 6. 6-28. 
Mauranen, Anna. 2012. Exploring ELF: Academic English shaped by non-native speakers. Cambridge, UK: Cambridge University Press.

Pilkinton-Pihko, Diane. 2010. English as a lingua franca lecturers' self-perceptions of their language use. Helsinki English Studies 6: 58-78.

Piller, Ingrid. 2011. Intercultural communication: A critical introduction. Edinburgh: Edinburgh University Press.

Seidlhofer, Barbara. 2004. Research perspectives on teaching English as a lingua franca. Annual Review of Applied Linguistics 24. 209-239.

Seidlhofer, Barbara. 2009. 'Accommodation and the idiom principle in English as a lingua franca'. Intercultural Pragmatics 6(2). 195-215.

Seidlhofer, Barbara. 2011. Understanding English as a Lingua Franca. Oxford, UK: Oxford University Press.

Shi-xu. 2001. Critical pedagogy and intercultural communication: Creating discourses of diversity, equality, common goals and rational-moral motivation. Journal of Intercultural Studies 22(3). 279-293.

Smit, Ute. 2009. Emic evaluations and interactive processes in a classroom community. In Anna Mauranen \& Elina Ranta (eds.), English as a lingua franca: Studies and findings, 200-224. Newcastle upon Tyne, UK: Cambridge Scholars Publishing.

Smit, Ute. 2010. English as a Lingua Franca in Higher Education: A Longitudinal Study of Classroom Discourse. Berlin, Germany: Mouton de Gruyter.

Smith, Larry E. \& Cecil L. Nelson. 1985. International intelligibility of English: Directions and resources. World Englishes 4(3). 333-342.

Toom, Auli \& Jukka Husu. 2012. Finnish teachers as 'makers of the many': Balancing between broad pedagogical freedom and responsibility. In Hannele Niemi, Auli Toom \& Arto Kallioniemi (eds.), Miracle of Education: The principles and practices of teaching and learning in Finnish schools, 39-54. Rotterdam, The Netherlands: Sense Publishers.

Wächter, Bernd \& Friedhelm Maiworm. 2008. English-Taught Programmes in European Higher Education: The Picture in 2007. Bonn, Germany: Lemmens.

Widdowson, Henry. 2012. ELF and the inconvenience of established concepts. Journal of English as a Lingua Franca 1(1). 5-26.

\section{Bionote}

Kaisa Hahl (MA in English philology, English teacher) is finalizing her $\mathrm{PhD}$ at the University of Helsinki in Finland. She researches and teaches in an EMI Subject Teacher Education Programme in the Department of Teacher Education. Her research focuses on the development of the international teacher education programme, including interculturality and the use of English as a lingua franca. 